International Research Journal of Management, IT \& Social Sciences
Available online at https://sloap.org/journals/index.php/irjmis/
Vol. 6 No. 4, July 2019, pages: 147 155
$\begin{aligned} & \text { ISSN: 2395-7492 } \\ & \text { https://doi.org/10.21744/irjmis.v6n4.669 }\end{aligned}$

\title{
Effect of Auditor's Role Conflict on Auditor's Stress with Core Self- Evaluations as Moderators
}

\author{
I Gede Bandar Wira Putra ${ }^{a}$ \\ I Putu Sudana ${ }^{b}$
}

\section{Article history:}

Received: 27 March 2019

Accepted: 31 May 2019

Published: 08 July 2019

\section{Keywords:}

auditor role conflict; auditor stress; core self-evaluations; model of stress; public accountant firm;

Author correspondence:

I Gede Bandar Wira Putra,

Udayana University, Faculty of Economics and Business, Udayana University, Denpasar, Indonesia

J1. PB.Sudirman, Denpasar Bali, Indonesia.

Email address: bandar.wiraputra@gmail.com

2395-7492@ Copyright 2019. The Author. This is an open-access article under the CC BY-SA license (https://creativecommons.org/licenses/by-sa/4.0/) All rights reserved.

\section{Introduction}

The high level of stress experienced by auditors places the accounting profession into one of ten careers with high levels of depression (Smith, 2010). The CityAM magazine website in the UK reported that Asian accountants experienced the highest daily stress compared to the United Kingdom, America, Africa and Canada (Spickernell, 2015). Stress can have an impact on dysfunctional behavior on auditors (Yuen et al., 2013). The manifestation of these consequences is reduced professional skepticism and audit efficiency, such as receiving evidence that is lacking in information, lack of recalculation or premature termination of procedures that take time and labor and reduction of the necessary analysis, which makes it difficult for auditors to identify inconsistent fluctuations between the audited party and its industrial information or anomalies between actual and expected data so that the auditor detects less accounting differences or misstatements and ultimately reduces audit quality (Margheim et al., 2005). The most recent case of the failure of auditors in detecting misstatements in their clients' financial statements in the spotlight is the case of two major accounting firms in the world of KPMG and PwC in conducting audits that are not according to standards so

${ }^{\text {a }}$ Faculty of Economics and Business, Udayana University, Denpasar, Indonesia

${ }^{\mathrm{b}}$ Faculty of Economics and Business, Udayana University, Denpasar, Indonesia 
that they are subject to millions of pounds in fines. KPMG was charged $\$ 6.2$ million (GBP 4.8 million) by the Securities and Exchanges Commission (SEC) for failing to find a 100-fold overstated on Miller Energy Resources assets in 2011. PwC was charged GBP 5.1 million and was criticized by Financial AccountingCouncil in the UK after acknowledging errors in the audit of the RSM Tenon Group knows the 2011 financial year (Hodgson, 2017).

The auditor in his assignment requires interaction with many people, with different desires and expectations that make him a number of role conflicts (Fisher, 2001). Auditors are always criticized whenever a company fails immediately after an unmodified audit opinion is reported or when the auditor fails to detect fraud (Ruhnke \& Schmidt, 2014). On the other hand, economic pressure also makes auditors experience role conflict which causes auditors to sacrifice professional ethics in order to obtain clients so that they compromise with economic motives (Koo \& Sim, 1999). This phenomenon can be explained by the model theory of stress (Robbins \& Judge, 2013). Model of stress illustrates that role conflict in an organization is a potential source of stress that triggers stress. Role conflict results in expectations that may be difficult to match or satisfy (Robbins \& Judge, 2013). This part of the stress process is also explained by role theory. Role theory states, if the behavior expected in an individual is inconsistent, he will experience stress, become dissatisfied, and appear less effective than if the expectations imposed on him are not contradictory (Rizzo et al., 1970).

Previous research regarding the effect of role conflict on stress concludes different results. Yongkang et al., (2014); Karimi et al., (2014) and Vanishree (2014), found a positive and significant role conflict on stress while Love (1987); Safaria et al., (2011), found empirical evidence that role conflict had no significant effect on stress. The inconsistency of research results regarding the effect of role conflict on stress raises questions about why different responses occur from the auditor on stress stemming from role conflict.

The model of stress (Robbins \& Judge, 2013) explains in situations where there is a source of stress that a person encounters, then the individual responds in a different way. Some people develop in stressful situations, while some others are overwhelmed in the situation. This is caused by variables that moderate the relationship of sources of stress to perceived stress called individual differences (individual differences), one of which is a personality (Robbins \& Judge, 2013). Personality is a pattern of relatively permanent traits and unique characteristics that provide consistency and individuality in one's behavior (Feist \& Feist, 2008; Kusumanegara et al., 2018; Farrastama et al., 2019).

Brunborg (2008) research, Judge et al., (2012); Gbadamosi \& Ross (2012); and Hainess III et al., (2013), concluded that core self-evaluations have an impact on stress reduction. Core self-evaluations will act as moderators namely high core self-evaluations reduce (that is, make less positive) the relationship between stress and tension (strains), while lower core self-evaluations improve (ie, make more positive) stress and tension relationships ( strain) (Tavousi, 2015). This study uses a model of stress as the underlying theory so that it can explain the relationship between auditor's role conflict, core self-evaluations and auditor's stress as a process of stress. Based on the theory and previous research, the researcher wanted to know the influence and auditor's role conflict and core self-evaluations on the stress of auditors working in Public Accountants registered in Bali Province.

\section{Materials and Methods}

Stress is a phenomenon of normal, important and unavoidable life that can cause temporary discomfort and longterm consequences (Dumitru \& Cozman, 2010). Stress is a trigger for some managerial and organizational problems. The issue that must be prioritized is how to eliminate sources of stress (Zorlu, 2012). Robbins \& Judge (2013), describe stress as a dynamic condition in which individuals are faced with opportunities, demands, and resources related to individual desires, where the results are felt to be doubtful and important. Cohen et al., (1983), stated that three things that become a core component of the stress that a person feels are how unpredictable, uncontrolled, and overloaded in the lives of individuals in general.

Role theory states, if the behavior expected by the individual is inconsistent, he will experience stress, become dissatisfied, and appear less effective than if the expectations imposed on him are not contradictory (Rizzo et al., 1970). The role played by a person can be a factor causing stress because someone in his life does not only play one role. Expectations of the environment around the individual for the role that is carried out, will provide pressures that can affect how individuals act. Stress can occur if individuals have difficulty interpreting these expectations, there is a lack of clarity about the role they play, or there is a conflict between expectations for one role and another (Hutami \& Chariri, 2011). This explains that role conflict affects the level of stress that occurs in individuals. The auditor's role conflict can be caused by the role structure of the auditor itself. Auditors have the role of monitoring and providing service providers to client managers (Koo \& Sim, 1999). 
Core self-evaluations are broad concepts that represent fundamental evaluations that people do about themselves and how they function in their environment. Individuals with positive core self-evaluations judge themselves in a positive way in a variety of situations. These individuals see themselves as capable, worthy, and have control over their lives. Individuals with negative self-evaluations cores tend to see themselves as less feasible than others, thinking of their failures and shortcomings, and seeing themselves as victims of their environment (Judge et al., 1997 in Judge et al., 1998). Robbins \& Judge (2013), states that core self-evaluation is the final conclusion that individuals have about their abilities, competencies, and values as individuals. The core self-evaluations concept consists of four personality traits, namely locus of control (beliefs about causal control over events in one's life), neuroticism (tendency to experience negative emotions), generalized self-efficacy (evaluation of one's performance ability in all situations), and self - esteem (the overall value that a person places in him) (Broucek, 2005; Jain et al., 2017; Yunita \& Saputra, 2019).

Brunborg (2008), concluded that core self-evaluations are the strongest predictor of work stress. Individuals with higher core self-evaluations experience less strain (stress) than stress. Core self-evaluations will act as moderators namely high core self-evaluations reduce (that is, make less positive) the relationship between stress and tension (strains), while lower core self-evaluations improve (ie, make more positive) stress and tension relationships (strain) (Tavousi, 2015). Individuals who value themselves positively (having high core self-evaluations) tend to actively cope with work stress situations. They tend to try to change the situation rather than let the pressure affect them. In other words, individuals with high core self-evaluations will assume less work pressure than individuals with low core selfevaluations (Brunborg, 2008).

Model of stress theory can explain the relationship between auditor's role conflict, core self-evaluations and auditor stress as a process of stress. Auditor's role conflict is a potential source of stress while the core self-evaluations are individual differences that influence the relationship between potential sources of stress and auditory stress.

Based on this, the hypothesis is formulated :

H1: Auditor's role conflict has a positive effect on auditor's stress.

H2: Core self-evaluations weaken the influence of auditor's role conflict on auditor's stress.

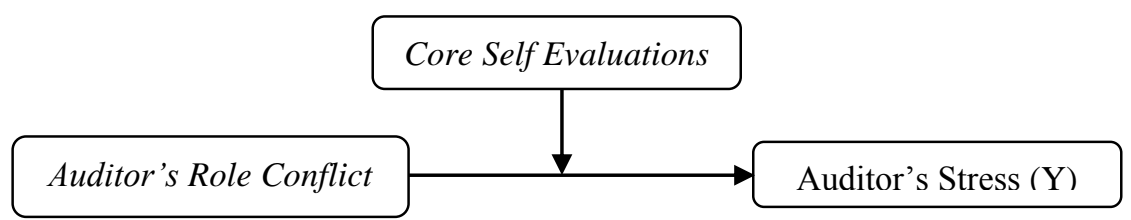

Figure 1. Research Model

Based on the Membership of the Indonesian Institute of Certified Public Accountants (IAPI) data in the 2017 Directory of Public Accountants and Public Accountants, in Bali Province, there are 11 (eleven) registered Public Accounting Firms. Of the 11 Public Accounting Firms, there were 2 (two) offices that were not operating, so that the population in this study were 82 auditors who worked in 9 (nine) Public Accounting Firms in Bali Province. The sampling technique used in this study is a nonprobability sampling method with a purposive sampling technique which produces 49 samples of auditors.

This study uses an instrument with a Likert scale with 5 scale points. The instrument used to measure auditor stress is the Perceived Stress Scale developed by Cohen et al., (1983), which consists of 10 statement items. This instrument is designed to measure how unpredictable, uncontrollable, and overloaded that participants feel in their lives in general. Auditor's role conflict is measured by indicators of structural inconsistencies, free engagement system, and expectation gap using instruments developed by Koo \& Sim, 1999; Dewi \& Dwiyanti, 2018; Sanjaya et al., 2019, in the form of 12 questions. Core self-evaluations are measured using Core Self-Evaluation Scales (CSES) adapted from the research of Judge et al., (2003), in the form of 12 items of statements relating to the core nature that occurs in a person.

This study uses an interaction test or often called Moderated Regression Analyzes (MRA) with the help of the Statistical Package for Social Science (SPSS) program. The statistical equation used is as follows:

$$
\mathrm{Y}=\alpha+\beta 1 . \mathrm{X} 1+\beta 2 . \mathrm{X} 2+\beta 3 . \mathrm{X} 1 \mathrm{X} 2+\varepsilon
$$

Putra, I. G. B. W., \& Sudana, I. P. (2019). Effect of auditor's role conflict on auditor's stress with core selfevaluations as moderators. International Research Journal of Management, IT and Social Sciences, 6(4), 147-155. https://doi.org/10.21744/irjmis.v6n4.669 


\section{Results and Discussions}

The regression analysis model used in this study is Moderated Regression Analyzes (MRA) with the help of IBM SPSS version 22 program. The Moderated Regression Analyzes equation that is formed from the results of processing this research data as follows :

$$
\mathrm{Y}=20,753+0,657 \mathrm{X} 1-0,060 \mathrm{X} 2-0,016 \mathrm{X} 1 \mathrm{X} 2
$$

Table 1

Moderated Regression Analyzes Testing Result

\begin{tabular}{lll}
\hline Variables & Beta & Sig. \\
\hline (Constant) & 20,753 & 0,010 \\
$\mathrm{X}_{1}$ & 0,657 & 0,002 \\
$\mathrm{X}_{2}$ & $-0,060$ & 0,762 \\
$\mathrm{X}_{1} \mathrm{X}_{2}$ & $-0,016$ & 0,014 \\
\hline
\end{tabular}

Information on hypothesis testing (table 1) can be stated that a constant of 20,753 with a significance level of 0.010 can be interpreted that although there is no auditor's role conflict and there is no interaction between the auditor's role conflict and core self-evaluations, auditor's stress tends to occur. Regression coefficient X1 has a positive value of 0.657 with a significance of 0.002 smaller than $\alpha=0.05$, meaning that when the auditor's role conflict variable increases, the auditor's stress will tend to increase with the assumption that other variables are constant and these results indicate that the auditor's role conflict has a positive effect on auditor's stress. Based on this result hypothesis 1 is accepted. Regression coefficient X2 has a negative value of 0.060 , meaning that when the core self-evaluations variable increases, auditor's stress will tend to decrease with the assumption that other variables are constant. The regression coefficient X1X2 has a negative value of 0.016 with a significance level of 0.014 smaller than $\alpha=0.05$, meaning that when the interaction between the auditor's role conflict and core self-evaluations increases, auditor's stress tends to decrease assuming other variables are constant and these results indicate core self Evaluations are able to weaken the influence of auditor's role conflict on auditor's stress. Based on this result hypothesis 2 is accepted. By noting that the moderating variable does not interact with the dependent variable, the moderation of the results of this interaction test is a pure moderator.

\section{The Effect of Auditor's Role Conflict on Auditor's Stress}

The results of testing hypotheses show evidence that auditor's role conflict has a positive effect on auditor's stress. This result means that the higher the auditor's role conflict experienced by the auditor, the higher the auditor's stress level and the lower the auditor's role conflict experienced by the auditor, the lower the auditor's stress level. The results of testing this hypothesis support the results of Yongkang et al., (2014); Karimi et al., (2014) and Vanishree (2014), research which showed a positive and significant role of role conflict on stress. The results of this study support role theory which states that if the behavior expected by the individual is inconsistent, he will experience stress, become dissatisfied and appear less effective than if the expectations imposed on him are not contradictory (Rizzo et al., 1970). Stress can occur if the individual has difficulty interpreting these expectations, there is a lack of clarity in the expectations of the role he is carrying out, or there is a conflict between expectations for one role and another (Hutami \& Chariri, 2011; Dewi et al., 2018; Aditya \& Kusuma, 2019).

Based on the results of respondents' answers to the questionnaire regarding auditor's role conflict, the highest average score was 2.22 from the statement "in conducting audit engagements, the client's bargaining position was stronger than mine". This shows that the auditors of the Public Accountants Office in Bali tend to experience pressure due to the low bargaining position in the audit engagement. The fact that audit services are a service that must be carried out in accordance with audit standards with the same output, namely the independent auditor's opinion, but the client can choose the auditor considering the offered fee can be a cause of role conflict to the auditor. 


\section{Core Self Evaluations Moderates the Effect of Auditor's Role Conflict on Auditor's stress}

The results of this study support the model of stress theory (Robbins \& Judge, 2013) because it provides empirical evidence that personality is an individual differences factor that influences the relationship between sources of stress on a person's perceived stress. This is shown from the results of testing in which the personality traits of core selfevaluations weaken the relationship between auditor's role conflict on auditor's stress. The higher auditor's role conflict causes higher auditor's stress, core self-evaluations are able to reduce the tension that occurs due to auditor's role conflict so that the auditor experiences less stress. A person's ability to handle stress is influenced by individual differences within them. Core self-evaluations as personality traits within the auditor explain how some auditors can handle a large amount of pressure, while others cannot deal with the same amount of pressure.

The results of this study can be taken into consideration for the Public Accounting Firm to use core self-evaluations personality tests in the auditor selection process, adjustments to the work area, or to guide auditor career development decisions. Personality is a predictor of potentially important work behavior. In a job interview, the Public Accountant Office is expected to assess the candidate's personality and its potential for good compatibility. This is important to do because core self-evaluations are proven to reduce the impact of role conflict on auditor's stress. The results of this study are expected to be able to provide an overview to the Public Accountant Office that the nature of personality plays an important role in the auditor's stress level when there is pressure from stress sources so as to provide empirical evidence for the model of stress theory.

The results also show that auditors of Public Accountants in Bali tend to be skeptical about their abilities and not easily adapt to problems in their work. This can be seen from the average questionnaire score was only 3.67 for the statement. The results of this study indicate that efforts need to be made to increase auditor confidence in their abilities. Public Accounting Firms in Bali can provide more training to their staff to increase auditor confidence in their abilities. Training on stress management and workload can also be provided so that auditors have knowledge in adapting to various situations in their work. The Indonesian Institute of Certified Public Accountants is also expected to always improve the quality of the training given to its members so that auditors are more confident in facing problems in their work.

\section{Conclusion}

Based on the results of the analysis and discussion in the previous chapter, it can be concluded that auditor's role conflict has a positive effect on auditor's stress. This shows that the higher the auditor's role conflict faced by the auditor, the higher the auditor's stress will be. Core self-evaluations weaken the influence of auditor's role conflict on auditor's stress. This shows that the high nature of auditor's core self-evaluations will weaken the tension experienced by auditors due to auditor's role conflict so that the auditor's stress level is lower than that of auditors with lower core self-evaluations.

The results of the study showed that auditors of Public Accountants in Bali Province experienced role conflicts caused by low bargaining position in the audit engagement. This can be caused by competition between Public Accountants in Bali Province so that clients have the ability to choose their auditors. This shows that it is necessary to maintain the values of professional ethics in the audit engagement so that competition between the Public Accounting Firm does not cause harm to the public accounting profession itself.

The results also indicate that efforts need to be made to increase the auditor's confidence in his ability. The Public Accountant Office can provide adequate training to its auditors to increase their confidence in their abilities. The Indonesian Institute of Certified Public Accountants is also expected to always improve the quality of the training given to its members so that auditors are more confident in dealing with sources of stress in their work.

The results of this study can also be taken into consideration by the Public Accounting Firm to conduct core selfevaluations personality tests in the auditor's acceptance process and to guide auditor career development decisions. The results of this study are able to provide an overview to the Public Accounting Firm that the nature of personality plays an important role in the auditor's stress level and provides empirical evidence for the model of stress theory.

Putra, I. G. B. W., \& Sudana, I. P. (2019). Effect of auditor's role conflict on auditor's stress with core selfevaluations as moderators. International Research Journal of Management, IT and Social Sciences, 6(4), 147-155. https://doi.org/10.21744/irjmis.v6n4.669 
Conflict of interest statement and funding sources

The authors declared that they have no competing interest.

Statement of authorship

The authors have a responsibility for the conception and design of the study. The authors have approved the final article.

Acknowledgments

The authors would like to thank the editorial team of IRJEIS for their valuable time to support, give advice in completing the present article. 


\section{References}

Aditya, A. G. D., \& Kusuma, M. G. W. (2019). The effect of tri hita karana culture in relationship between work stress and internal auditor performance. International Research Journal of Management, IT and Social Sciences, 6(2), 72-78. https://doi.org/10.21744/irjmis.v6n2.610

Broucek, W. G. (2005). An examination of core self evaluations (CSE) in an academic setting: Does CSE generalize to students?. Journal of College Teaching \& Learning (TLC), 2(2). https://doi.org/10.19030/tlc.v2i2.1779

Brunborg, G. S. (2008). Core self-evaluations: A predictor variable for job stress. European Psychologist, 13(2), 96102. https://doi.org/10.1027/1016-9040.13.2.96

Cohen, S., Kamarck, T., \& Mermelstein, R. (1983). A global measure of perceived stress. Journal of health and social behavior, 385-396. http://dx.doi.org/10.2307/2136404

Dewi, I. G. A. A. P., \& Dewi, P. P. (2018). Big Five Personality, Ethical Sensitivity, and Performance of Auditors. International Research Journal of Management, IT and Social Sciences, 5(2), 195-209.

Dewi, P. P., \& Dwiyanti, K. T. (2018). Professional commitment, self-efficacy and ethical decision auditor. International Research Journal of Management, IT and Social Sciences, 5(6), 93-104. https://doi.org/10.21744/irjmis.v5n6.379

Dumitru, V. M., \& Cozman, D. (2012). The relationship between stress and personality factors. Human and Veterinary Medicine, 4(1), 34-39.

Farrastama, D. N., Asmony, T., \& Hermanto, H. (2019). Effect of emotional intelligence on counterproductive work behavior with job stress as an intervening variable. International Journal of Social Sciences and Humanities, 3(1), 14-25. https://doi.org/10.29332/ijssh.v3n1.248

Feist, J., \& Feist, G. J. (2009). Theories of personality.

Fisher, R. T. (2001). Role stress, the type A behavior pattern, and external auditor job satisfaction and performance. Behavioral Research in Accounting, 13(1), 143-170. https://doi.org/10.2308/bria.2001.13.1.143

Gbadamosi, G., \& Ross, C. (2012). Perceived stress and performance appraisal discomfort: The moderating effects of core self-evaluations and gender. Public Personnel Management, 41(4), 637-659. https://doi.org/10.1177/009102601204100404

Haines III, V. Y., Harvey, S., Durand, P., \& Marchand, A. (2013). Core Self-Evaluations, Work-Family Conflict, and Burnout. Journal of Marriage and Family, 75(3), 778-793. https://doi.org/10.1111/jomf.12026

Hodgson, C. (2017). 'Big Four' accounts KPMG and PwC have both just been fined millions, Business Insider Business Insider Singapore, Bussiness Insider Singapore. Retrieved from https://www.businessinsider.my/kpmgfined-sec-pwc-fined-frc-2017-8/ (Cited 22 September 2017).

Hutami, G., \& Chariri, A. (2011). Pengaruh Konflik Peran dan Ambiguitas Peran Terhadap Komitmen Independensi Auditor Internal Pemerintah Daerah (Studi Empiris pada Inspektorat Kota Semarang) (Doctoral dissertation, Universitas Diponegoro).

Jain, P., Billaiya, R., \& Malaiya, S. (2017). A correlational analysis of academic stress in adolescents in respect of socio-economic status. International Journal of Physical Sciences and Engineering, 1(1), 68-71. https://doi.org/10.21744/ijpse.v1i1.14

Judge, T. A., Erez, A., Bono, J. E., \& Thoresen, C. J. (2003). The core self-evaluations scale: Development of a measure. Personnel psychology, 56(2), 303-331. https://doi.org/10.1111/j.1744-6570.2003.tb00152.x

Judge, T. A., Ilies, R., \& Zhang, Z. (2012). Genetic influences on core self-evaluations, job satisfaction, and work stress: A behavioral genetics mediated model. Organizational Behavior and Human Decision Processes, 117(1), 208-220. https://doi.org/10.1016/j.obhdp.2011.08.005

Judge, T. A., Locke, E. A., Durham, C. C., \& Kluger, A. N. (1998). Dispositional effects on job and life satisfaction: The role of core evaluations. Journal of applied psychology, 83(1), 17. https://doi.org/10.1037//0021-9010.83.1.17

Karimi, R., Omar, Z. B., Alipour, F., \& Karimi, Z. (2014). The influence of role overload, role conflict, and role ambiguity on occupational stress among nurses in selected Iranian hospitals. International Journal of Asian Social Science, 4(1), 34-40.

Kusumanegara, I. S., Asmony, T., \& Numayanti, S. (2018). Work-family conflict on turnover intention regarding work stress as intervening variable. International Journal of Social Sciences and Humanities, 2(2), 141-154. https://doi.org/10.29332/ijssh.v2n2.153

Love, K. A. (1987). Gender differences in occupational role conflict and psychological well-being, job satisfaction, job involvement and stress.

Margheim, L., Kelley, T., \& Pattison, D. (2005). An empirical analysis of the effects of auditor time budget pressure and time deadline pressure. Journal of Applied Business Research (JABR), 21(1).

Putra, I. G. B. W., \& Sudana, I. P. (2019). Effect of auditor's role conflict on auditor's stress with core selfevaluations as moderators. International Research Journal of Management, IT and Social Sciences, 6(4), 147-155. 
Mo Koo, C., \& Seog Sim, H. (1999). On the role conflict of auditors in Korea. Accounting, Auditing \& Accountability Journal, 12(2), 206-219. https://doi.org/10.1108/09513579910270110

Rizzo, J. R., House, R. J., \& Lirtzman, S. I. (1970). Role conflict and ambiguity in complex organizations. Administrative science quarterly, 150-163. https://doi.org/10.2307/2391486

Robbins, S. P., \& Judge, T. A. (2013). Organizational Behavior (wydanie 15).

Ruhnke, K., \& Schmidt, M. (2014). The audit expectation gap: existence, causes, and the impact of changes. Accounting and Business research, 44(5), 572-601. https://doi.org/10.1080/00014788.2014.929519

Safaria, T., bin Othman, A., \& Wahab, M. N. A. (2011). The Role of Leadership Practices on Job Stress among Malay Academic Staff: A Structural Equation Modeling Analysis. International Education Studies, 4(1), 90-100. https://doi.org/10.5539/ies.v4n1p90

Sanjaya Adi Putra, G., \& Dwirandra, A. A. N. B. (2019). The effect of auditor experience, type of personality and fraud auditing training on auditors ability in fraud detecting with professional skepticism as a mediation variable. International Research Journal of Management, IT and Social Sciences, 6(2), 31-43. https://doi.org/10.21744/irjmis.v6n2.604

Smith, E. E. (2010). Ten Careers with High Rates of Depression, Psychologytoday. Retrieved from https://www.psychologytoday.com/us/blog/not-born-yesterday/201011/ten-careers-high-rates-depression (cited 8 April 2017).

Spickernell, S. (2015). The Stress of Accounting: One in Three UK Accountants has Suffered Mental Health Problems, CityA.M. Retirieved from https://www.cityam.com/stress-finance-one-three-uk-accountants-has-suffered-mentalhealth-problems/ (cited: 8 April 2017).

Tavousi, M. N. (2015). Dispositional effects on job stressors and job satisfaction: The role of core evaluations. Procedia-Social and Behavioral Sciences, 190, 61-68. https://doi.org/10.1016/j.sbspro.2015.04.917

Vanishree, P. (2014). Impact of role ambiguity, role conflict and role overload on job stress in small and medium scale industries. Research Journal of Management Sciences, 3(1), 10-13.

Yongkang, Z., Weixi, Z., Yalin, H., Yipeng, X., \& Liu, T. (2014). The relationship among role conflict, role ambiguity, role overload and job stress of Chinese middle-level cadres. Chinese Studies, 3(01), 8. https://doi.org/10.4236/chnstd.2014.31003

Yuen, D. C., Law, P. K., Lu, C., \& Qi Guan, J. (2013). Dysfunctional auditing behaviour: empirical evidence on auditors' behaviour in Macau. International Journal of Accounting \& Information Management, 21(3), 209-226. https://doi.org/10.1108/ijaim-12-2012-0075

Yunita, P. I., \& Saputra, I. G. N. W. H. (2019). Millennial generation in accepting mutations: Impact on work stress and employee performance. International Journal of Social Sciences and Humanities, 3(1), 102-114. https://doi.org/10.29332/ijssh.v3n1.268

Zorlu, K. (2012). The perception of self-esteem and self-efficacy as transforming factors in the sources of role stress and job satisfaction relationship of employees: A trial of a staged model based on the artificial neural network method. African Journal of Business Management, 6(8), 3014-3025. https://doi.org/10.5897/ajbm11.2345 


\section{Biography of Authors}

\begin{tabular}{|l|l||} 
I Gede Bandar Wira Putra graduated his bachelor degree in Faculty of Economics and \\
Bussines at Udayana University. He finished his master degree in Faculty of \\
Economics and Bussines at Udayana University. \\
Email: bandar.wiraputra@gmail.com
\end{tabular}

Putra, I. G. B. W., \& Sudana, I. P. (2019). Effect of auditor's role conflict on auditor's stress with core selfevaluations as moderators. International Research Journal of Management, IT and Social Sciences, 6(4), 147-155. https://doi.org/10.21744/irjmis.v6n4.669 